\title{
Margin Analysis And Marketing Efficiency Of Dendrobium Orchid Plant
}

\section{Tri Waluyo}

\{tw@civitas.unas.ac.id\}, Fakultas Pertanian Universitas Nasional Jakarta, Indonesia.

\author{
Abd. Rahman Kadir \\ \{Rahmankadir90@yahoo.com\}, Faculty of Economics and Business,Hasanuddin University, Makassar, Indonesia.
}

\section{Nuraeni Kadir}

\{nuraeinikadir@gmail.com\},Faculty of Economics and Business,Hasanuddin University, Makassar, Indonesia.

\author{
Andi Aswan \\ \{andiaswanp@yahoo.com\},Faculty of Economics and Business,Hasanuddin University, Makassar, Indonesia.
}

\begin{abstract}
The results, it can be concluded:The marketing channel for dendrobium orchids which is formed in Ragunan OrchidGarden, South Jakarta consists of 4 (four) forms, namely: Farmers - Consumers, Farmers - Retailers Consumers, Farmers - Large Traders - Consumers and finally Farmers - Large Traders - Retailers Consumers. The marketing margin of dendrobium orchids obtained by retailers with a reference market in Bekasi has the highest value of Rp. 15,000.00 per pot. While the marketing margin of the dendrobium orchid obtained by retailers with the reference market in Jakarta also has the highest value of Rp. 17,500.00 per pot.The marketing channel from farmers directly to consumers has the highest marketing efficiency that is equal to $50 \%$.
\end{abstract}

Keywords:

Marketing Channel, Margin Analysis, Marketing Efficiency and Dendobrium Orchid Plant. Article Received: 18 October 2020, Revised: 3 November 2020, Accepted: 24 December 2020

\section{Introduction}

\subsection{Background}

Many orchids are known as a happy greeting, good decoration in the house and hotel is one of the plants that have a high economic value. This is proven by the many requests for orchid flowers. In addition, because of the many variations of orchids, which is one of the advantages of these plants.

In Indonesia, there are many types of orchids that can be developed and cultivated properly given the favorable climatic conditions. The growth of orchids both vegetative and generative is not only determined by genetic factors, but also influenced by environmental factors such as light, temperature, humidity, and growing media.

The orchid plant with all its unique characteristics has attracted the attention of botanists since two centuries ago. Orchids in taxonomic classification, including in the family Orchidaceae, a family that is very large and very varied. This family consists of 800 genera with no less than 25,000 species.

Dendrobium orchid species is one of the largest orchid genus in the world, and is estimated to consist of 1600 species. Generally grows spread in South Asia, India and Sri Lanka. In East Asia widely cultivated by the people of Japan, Taiwan and Korea. In Southeast Asia, dendrobium is a 
mainstay of Thailand, Indonesia and the Philippines and extends to New Zealand. In Indonesia, dendrobium is often found in forests around Java Island, Kalimantan Island, Sumatra Island, Irian Jaya Island, Maluku and Nusa Tenggara (Gunawan, 2005).

\subsection{Formulation of the problem}

Assauri, (2002) said marketing is an activity of delivering products to consumers in the right time. This marketing process is also needed on orchids, so that orchids can reach consumers in the right time. Until now, orchid marketing channels are still determined by large traders. Usually the big traders buy orchids from farmers in Ragunan Orchid Garden with a price range of Rp. 17,500 50,000 per pot depending on the type and size.

This research aims to determine the marketing of dendrobium orchids that are formed in the Ragunan Orchid Garden, knowing the marketing margins of dendrobium orchids in the Ragunan Orchid Garden, the extent of marketing efficiency dendrobium orchid in the Ragunan Orchid Garden.

\section{Literature Review}

\subsection{Orchid Plants}

Setiawan (2005), said that the orchiddendrobium plant comes from the word dendro which means tree and bios which means life. This orchid is the most populair type, both among hobbyists and growers of orchids. Usually, orchid lovers start a business by growing this type of orchid because its market share is around 50\% of the total orchid market (in units of plants in pots).

\subsection{Potential of the Dendrobium Market}

According to Anonymous (2005) that in the last decade there was a rapid development of the type of dendrobium. The last two years show a new round of orchid business, both for potted orchids and cut flowers as shown in the following table.

Table 1.Orchid harvest area (in $\mathrm{M}^{2}$ ) in DKI Jakarta Province

\begin{tabular}{|c|c|c|c|c|c|}
\hline \multirow{2}{*}{ No } & \multirow{2}{*}{ Commodity } & \multicolumn{4}{|c|}{ Year } \\
\hline & & 2012 & 2013 & 2014 & 2015 \\
\hline 1. & Orchid & 150.795 & 84.075 & 181.541 & 188.561 \\
\hline
\end{tabular}

Source: DKI Jakarta Provincial Agriculture and Forestry Office, (2016)

\subsection{Marketing and Marketing Channels}

Marketing is a human activity that is directed to meet and satisfy the needs and desires through the exchange process. Marketing activities actually develop since there are human needs and efforts to meet human needs through exchange (Assauri, 2002). Marketing channel is a marketing chain that involves marketing institutions in the delivery of products to consumers.

For the government, the role of marketing in addition to providing employment opportunities is also at the same time as an effort to get a source of state revenue both from customs and excise, foreign exchange earnings, corporate taxes and other levies. In addition, through marketing the government can determine various policies, especially import duty and import ban policies, price subsidy policies, and government purchasing policies (Assauri, 2002).

\subsection{Marketing Margin}

Marketing margin is the difference in price paid by consumers for a product with the price received byproducers for the same product (Tukan, 2000).

The existence of marketing activities that are activities of delivering products to the hands of consumers at the right time, causing the emergence of marketing margins. This is due to the emergence of wholesalers and retailers who are marketing institutions. Each marketing institution wants to get profit, so the price paid by each marketing institution is also different. So the price at the farm level will be lower than the price at the wholesale level and the price at the 
wholesale level will also be lower than the price at the retail level.

Efficiency is defined as savings in using expenses to get better results. From time to time, producers think abouthow to do efficient business processes so that they can ultimately produce products that are affordable to consumers with realistic expenses (Rintoni, 2007).

\section{Research Framework and Hypotheses Of} Research

\subsection{The flow of thinking}

Orchid can reach consumers generally through marketing channels that apply to the present, namely farmers to large traders then retailers and finally to consumers. The marketing channel requires marketing institutions namely wholesalers and retailers to make it easier for consumers to get products. In orchid marketing, it takes several stages such as packaging and transportation so that the orchid can reach consumers. In general, orchid plants are packaged by wrapping the pot in a newspaper and then putting it in a thick cardboard or box that has been given a hole (Setiawan, 2005)

Pranowo, (2006) in his research analyzed marketing margins of seaweed (Eucheuma cottonii) with quantitative analysis methods and presented in tabulated form. The results of his research indicate that the marketing margins obtained by traders are smaller than the marketing margins obtained by retailers.

From the above line of thinking, it can be made a flowchart of thinking from this research, ranging from orchid growers to large traders then to retailers to orchids to the hands of consumers, so that marketing margins arise between the prices paid by consumers and prices received producer. The flow of thought of this research can be seen in Figure 1.

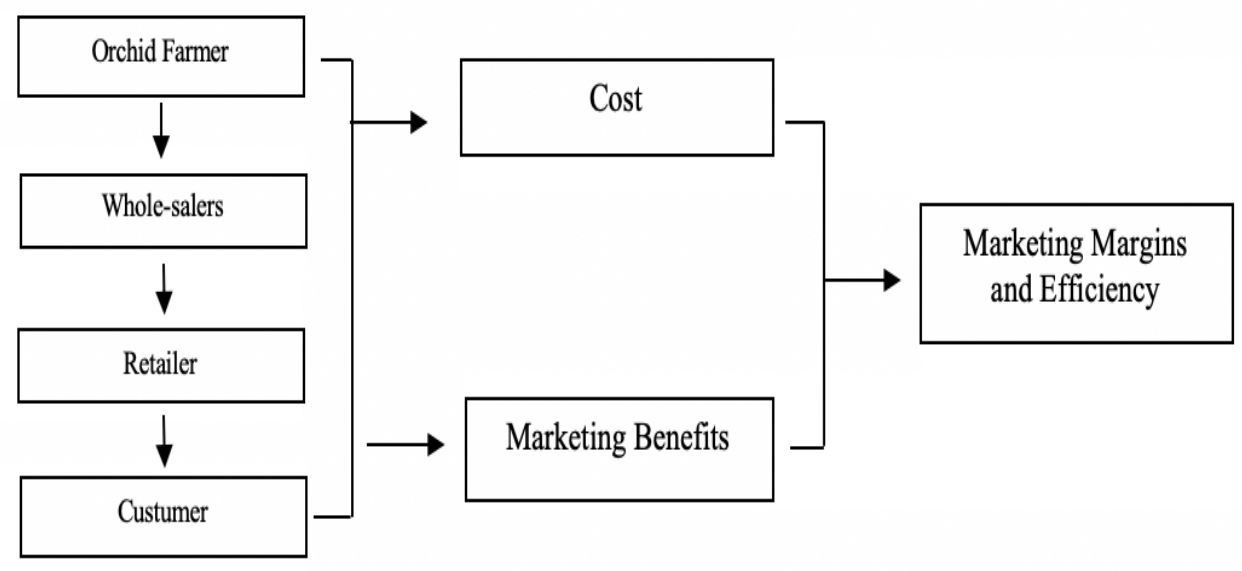

Fig.1. Flow of Thought About Margin Analysis and Marketing Efficiency of Dendrobium Orchid Plants

\subsection{Hypothesis:}

Suspected research hypotheses that can be drawn are:

1. Dendrobium orchid marketing channels that occur in Ragunan Park are Farmers $\rightarrow$ Wholesalers $\rightarrow$ Retailers $\rightarrow$ Consumers.

2. Margin and marketing efficiency at the retailer level has the highest value.

3. The marketing channels from the land directly to consumers have the highest marketing efficiency.

\section{Research Methodology}

\subsection{Research Location and Time}

The selection of research sites is based on several considerations, including strategic and easily accessible locations and complete facilities for conducting research, so Ragunan Orchid Garden is chosen \pm 12 kilometers from the center of Jakarta which is administratively included in the Ragunan Village, Pasar Minggu District, South Jakarta. This research was conducted in February to May 2016. 


\subsection{Data Types and Sources}

The type of data collected consists of primary data and secondary data. Primary data were obtained from direct interviews using a questionnaire. Secondary data was obtained by searching literature, books, research reports, thesis, dissertations and scientific works related to research problems.

\subsection{Population and Sample}

The research method used in this study is the survey method. The survey method is a study that takes a sample from one population and uses a questionnaire as a data collection tool.

The survey was conducted using a simple random technique (Simple Random Sampling). According to Umar, (2005) random sampling is a method of selecting sample sizes in which each member of the population has an equal chance of being selected as a sample member.

Through interviews with farmers in Ragunan Orchid Garden it is known that retailers who buy dendrobium orchids in Ragunan Orchid Garden number \pm 25 people, and the minimum number of consumers \pm 30 people per month. Based on information obtained from farmers in Ragunan Orchid Garden it is known that large traders from Bekasi who buy dendrobium orchids in Ragunan Orchid Garden number \pm 5 people. Retailers who buy orchids from wholesalers \pm 10 people. Consumers of dendrobium orchids in Bekasi according to information from wholesalers and retailers number a minimum of \pm 10 people per month.

\subsubsection{Marketing Margin Analysis}

Marketing margin is the difference in price paid by consumers for a product with the price received by producers for the same product. According to Tukan (2000) mathematically as follows:

$$
\begin{aligned}
& \mathrm{Mj}=\mathrm{Psi}-\mathrm{Pbi} \\
& \text { Information : } \\
& \mathrm{Mj}=\text { margin of marketing agency } \\
& \mathrm{Psi}=\text { selling price of the } \mathrm{i} \text { marketing agency } \\
& \mathrm{Pbi}=\text { purchase price of the } \mathrm{i} \text { marketing agency }
\end{aligned}
$$

\subsubsection{Marketing Efficiency Analysis}

The value of marketing efficiency can be calculated using parameters according to Desai (2001) in Andayani (2007), as follows:

Marketing Efficiency =Marketing Margin/Selling price $\mathrm{x} 100 \%$

\section{Research Results and Discussion}

\subsection{Ragunan Orchid Garden Overview}

Ragunan Orchid Garden stands on an area of 5 hectares with facilities and infrastructure consisting of 42 lots used for orchid agribusiness activities, 2 lots for parking area, 1 lot for marketing offices, and there are waterways and footpaths that lead to the plots. The marketing office area consists of information offices for visitors, laboratories, saprotan shops and multipurpose buildings that can be used as meeting rooms, seminars, and can also be used as training rooms. Safety facilities at Ragunan Orchid Garden are available in 24 hours. Table 2 shows the sale of dendrobium pot orchids in Ragunan Orchid Gardenin 2016.

Table 2. Dendrobium Orchid Sales in Ragunan Orchid Garden in 2016

\begin{tabular}{clcccc}
\hline No. & Month & $\begin{array}{c}\text { Sales Amount ( } \\
\text { pot })\end{array}$ & No. & Month & $\begin{array}{c}\text { Sales Amount ( } \\
\text { pot })\end{array}$ \\
\hline 1. & January & 24.890 & 7. & July & 26.271 \\
2. & February & 24.960 & 8. & August & 29.871 \\
3. & March & 29.840 & 9. & September & 29.105 \\
4. & April & 30.850 & 10. & October & 27.105 \\
\hline
\end{tabular}




\begin{tabular}{|c|c|c|c|c|c|}
\hline 5 . & May & 30.240 & 11. & November & 25.215 \\
\hline 6. & June & 29.167 & 12. & December & 24.125 \\
\hline
\end{tabular}

Source: Taman AnggrekRagunan, (2016)

\subsection{Characteristics of Respondents}

Based on the results of research, in the Ragunan Orchid Gardenthere are 32 dendrobium orchid farmers, big traders (from outside Jakarta such as Bogor, Bekasi, Bandung, Yogyakarta, Semarang, Bali, Kalimantan, and other cities in Indonesia), and retailers (originating from Jakarta and surrounding areas), as well as the latest consumers.

The farmers respondents in this research are mostly in age group 46-55 years old, with various education level, and made up of 11-15 years of experience in the gworing orchids. Meanwhile, the wholesalers are mostly in age group 30-40 years old, with various education level and are experienced wholesalers for working in the field for 6-10 years.

On the other hand the orchid retailers traders are mostly in age group 25-35 years, with various education level, and 6-10 years of working experience in the business.

Consumers of dendrobium orchids outside Jakarta, namely in Bekasi, have a diverse age distribution ranging from ages 25 to 65 years, and most of the orchid consumer respondents are in the age group 36-45 years. The level of education also varies, most consumers of dendrobium orchids have high school / high school education levels.Experience as a hobby of orchid consumers is also diverse, as seen in the majority of orchid consumers in Bekasi, consisting of less experienced orchid consumers, with experiences as hobbyist orchid between $1-15$ years. Consumers usually look for different types of orchids to add to the collection, with the intensity of buying 1-3 times in a month and the number of orchids purchased for 1-3 pots for one transaction.

\subsection{Marketing Channel}

Marketing of dendrobium orchids from farmers to consumers involves several marketing institutions, including large traders and retailers. These marketing agencies carry out a series of activities to the end of the consumer.

The marketing channels of dendrobium orchids formed in Ragunan Orchid Gardenhave 4 (four) marketing channels, as shown in figure 3.

Fig 3. Dendrobium Orchid Marketing Channels in Ragunan Orchid Garden.

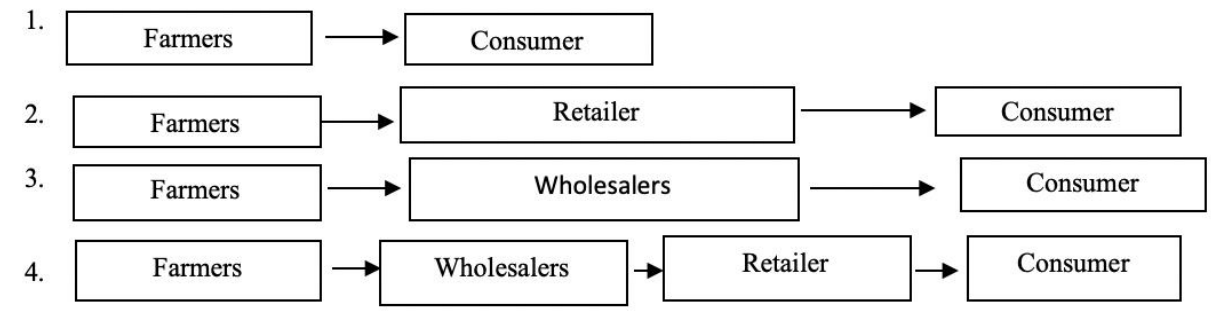

\subsection{Marketing Function}

The marketing function is an activity carried out by marketing institutions that can expedite the process of delivering goods or services from producers to consumers. The marketing function that occurs in marketing institutions can be seen in Table 5 .

Table 5. Marketing Functions of the Dendrobium Orchid Marketing Institute in Ragunan Orchid Garden, SouthJakarta.

\begin{tabular}{llccc}
\hline No. & Marketing function & Farmers & Wholesalers & Retailer \\
1. & Sales & $\checkmark$ & $\checkmark$ & $\checkmark$ \\
\hline
\end{tabular}




\begin{tabular}{lllll} 
2. & Purchase & $\checkmark$ & $\checkmark$ & $\checkmark$ \\
3. & Processing & $\checkmark$ & & \\
4. & Storage & $\checkmark$ & $\checkmark$ & $\checkmark$ \\
5. & Transportation & $\checkmark$ & $\checkmark$ & $\checkmark$ \\
6. & Sorting & $\checkmark$ & & $\checkmark$ \\
7. & Risk Management & $\checkmark$ & $\checkmark$ & $\checkmark$ \\
8. & Market Information & $\checkmark$ & $\checkmark$ & $\checkmark$ \\
\hline
\end{tabular}

Source: Primary data processed (2016)

\subsubsection{Marketing functions in the Orchid Garden}

Marketing functions occurring at the level of dendrobium orchids are sales, purchases, processing, storage, transportation, sorting, risk management and market information. The intended sale is the sale of dendrobium orchids to buyers consisting of large-scale traders, retailers and final consumers. Purchases made by farmers buy the seeds of dendrobium seeds from the breeding place of orchids. Processing is carried out by farmers such as processing activities such as fertilizer application, planting media, pest and disease control by using insecticides and fungicides, as well as watering the mixed-flower fertilizer and being ready for sale. The intended storage is the storage carried out by farmers during the period before the sale. Transportation is carried out when farmers buy orchid seeds from orchid breeding sites. Sorting is done by farmers to separate dendrobium orchid based on the size and quality of certain farmers. In general, risk management at the farmer level of orchids is very small because the marketed dendrobium orchids will usually be sold out within one production period, especially for orchids that have flowered. Market information is obtained by farmers in Ragunan Orchid Garden, usually through traders or fellow orchid farmers, exhibitions, and collaborating with related agencies.

\subsubsection{Marketing Functions at the Wholesaler Level}

The marketing functions that occur at the wholesaler level are sales, purchases, storage, transportation, risk management and market information. Sales at the wholesaler level are sales of dendrobium orchids to buyers consisting of retailers and consumers. Purchases made by large traders, namely flowering dendrobium orchids from Ragunan Ragunan Park. The storage in question is the storage carried out by large traders as long as the orchid has not been sold. Transportation is carried out when a large trader buys dendrobium orchids from RagunanOrchid Garden. Similar to risk management at the farm level, although there is risk management at the wholesaler level is also relatively small because the selling time of dendrobium orchids is relatively short, usually dendrobium orchids will be sold out within 2 days to 1 week. Market information is usually obtained from fellow large traders when making transactions at Ragunan Orchid Garden, as well as through retailers who usually meet directly with end customers.

\subsubsection{Marketing Functions at the Retailer's Level}

The marketing functions that occur at the retailer's level are sales, purchases, storage, transportation, sorting, risk management and market information. The sale in question is the sale of dendrobium orchids to consumers. Purchases made by retailers are purchases of flowering dendrobium orchids from Ragunan Orchid Garden or purchases made by retailers outside Jakarta through large traders who buy flowering dendrobium orchids from Ragunan Orchid Garden. The intended storage is the storage carried out by the retailer as long as the orchid has not been sold. Transportation is carried out when retailers buy dendrobium orchids from Ragunan Ragunan Park or buy through large traders for retailers outside Jakarta. Sorting is done to separate dendrobium orchids that are 
damaged and withered due to transportation at the time of purchase from large traders and sales to consumers. Risk management at the retailer level is relatively greater compared to the risk at the farmer and wholesaler level. Although the selling time of dendrobium orchids at the retailer level is also relatively short, which ranges from 2 days to 1 week, but because these retailers make purchases and sales by traveling around using transportation equipment such as motorcycles and carts, which can cause orchids to fall out or orchid plants broken and withered. Market information is usually obtained from large traders or other retailers at the time of the transaction at the location of large traders.

\subsection{Marketing Margin Analysis}

Marketing margin is the difference in price paid by consumers for a product with the price received by producers for the same product. The emergence of marketing margins is due to marketing costs and marketing profits. Marketing costs represent costs incurred for marketing purposes consisting of costs for buying orchids, sorting, repotting, transportation, renting space, labor, cleaning, security, electricity and other costs needed in marketing orchids. While marketing profit is the amount of money to be obtained from the sale after deducting marketing costs

The study focused on orchid farmers in Ragunan Orchid Garden with large traders from outside Jakarta, and farmers with retailers in Jakarta, and farmers with consumers from Jakarta and surrounding areas. So the marketing margins that will be analyzed are the marketing margins of farmers in Ragunan Orchid Gardenwith large traders who come from outside Jakarta, and farmers with retailers in Jakarta, and farmers with consumers from Jakarta and surrounding areas.

In this research, wholesalers, retailers, and consumers from outside Jakarta are focused on wholesalers, retailers, and consumers from the Bekasi area. The study was conducted with only one region, because to facilitate research because of limited time and cost, most respondents, especially large traders, came from outside Jakarta such as Bogor, Bekasi, Bandung, Yogyakarta, Semarang, Bali, Kalimantan, Sumatra and other big cities in Indonesia.

\subsubsection{Dendrobium Orchid Marketing Margin AnalysisfromFarmers inRagunan Orchid GardentoWholesalers,}

\section{Retailers and Consumers}

The difference in marketing margins arising between the analysis of the marketing margins of dendrobium orchids from farmers in Ragunan Orchid Garden to large traders, and retailers with the analysis of marketing margins of dendrobium orchids from farmers in Ragunan Orchid Gardento consumers can be seen in Table 10. and Table 11. as shown presented below.

Table 6. Dendrobium Orchid Marketing Margin Analysis from Farmers in Ragunan Orchid GardentoWholesalers and Retailers

\begin{tabular}{llc}
\hline \multicolumn{1}{c}{ Description } & \multicolumn{1}{c}{ Rp/Pot } & \% (of total costs) \\
A.Cost of goods sold & 10.000 & 83,3 \\
B. Marketing Costs & 2.000 & 16,7 \\
- transportation & 500 & 4,2 \\
- Rent & 350 & 2,9 \\
- Labor & 600 & 5,0 \\
- Telephone & 200 & 1,7 \\
- electricity & 100 & 0,8 \\
- packaging & 100 & 0,8 \\
- security & 75 & 0,6 \\
- Cleanliness & 75 & 0,6 \\
\hline
\end{tabular}




\begin{tabular}{llc}
\hline C. Total Cost & 12.000 & 100,0 \\
D. Advantages & 5.500 & 45,8 \\
E. Selling price & 17.500 & 145,8 \\
F. Marketing Margin & 7.500 & 62,5 \\
Risk of Profit to Costs $(\pi / C)(\pi / C$ & & 45,8
\end{tabular}

Source: Primary data processed (2016)

In the analysis of marketing margins of dendrobium orchids from farmers in the Ragunan Orchid Garden, large traders and retailers in Table 10. the large marketing margin is $\mathrm{Rp} 7,500.00$ per pot. Whereas in the marketing margin analysis of dendrobium orchids from farmers in Ragunan Orchid Garden to consumers in Table 11. the amount is $\mathrm{Rp} 10,000.00$ per pot.

The difference in marketing margins is due to the selling price from farmers to large traders and retailers being cheaper than selling prices from farmers to consumers, so that the profits from the sale of farmers to large traders and retailers will be smaller than the profits from the sales of farmers to consumers. The difference in selling prices of dendrobium orchids which are cheaper than farmers in Ragunan Orchid Gardento large traders and retailers with selling prices to consumers, is generally influenced by the number of dendrobium orchids that are bought by large traders and retailers usually in large quantities and for resale, whereas consumers buy orchids in small quantities and for private collections.

In this marketing margin analysis and subsequent depreciation cost components are not used because the quality of dendrobium orchids is good and the risk of death is considered to be absent.

Analysis of the marketing margins of dendrobium orchids from farmers in Ragunan Orchid Gardento consumers can be seen in table 11. below.

Table 7. Dendrobium Orchid Marketing Margin Marketing MarginAnalysis from Farmers in Ragunan Orchid Garden to Consumers

\begin{tabular}{lrr}
\hline \multicolumn{1}{c}{ Description } & Rp/Pot & $\%$ \\
& & (of total costs) \\
A.Cost of goods sold & 10.000 & 83,3 \\
B. Marketing Costs & 2.000 & 16,7 \\
- transportation & 500 & 4,2 \\
- Rent & 350 & 2,9 \\
- Labor & 600 & 5,0 \\
- Telephone & 200 & 1,7 \\
- electricity & 100 & 0,8 \\
- packaging & 100 & 0,8 \\
- security & 75 & 0,6 \\
- Cleanliness & 75 & 0,6 \\
C. Total Cost & 12.000 & 100,0 \\
D. Advantages & 8.000 & 66,6 \\
& & \\
& & \\
E. Selling price & 20.000 & 166,6 \\
F. Marketing Margin & 10.000 & 83,3 \\
\end{tabular}


Risk of Profit to Costs $(\pi / \mathrm{C})$

66,6

Source: Primary data processed (2016)

Table 8. Dendrobium OrchidAnalysis from Wholesalers in Bekasito Retailers in Bekasi

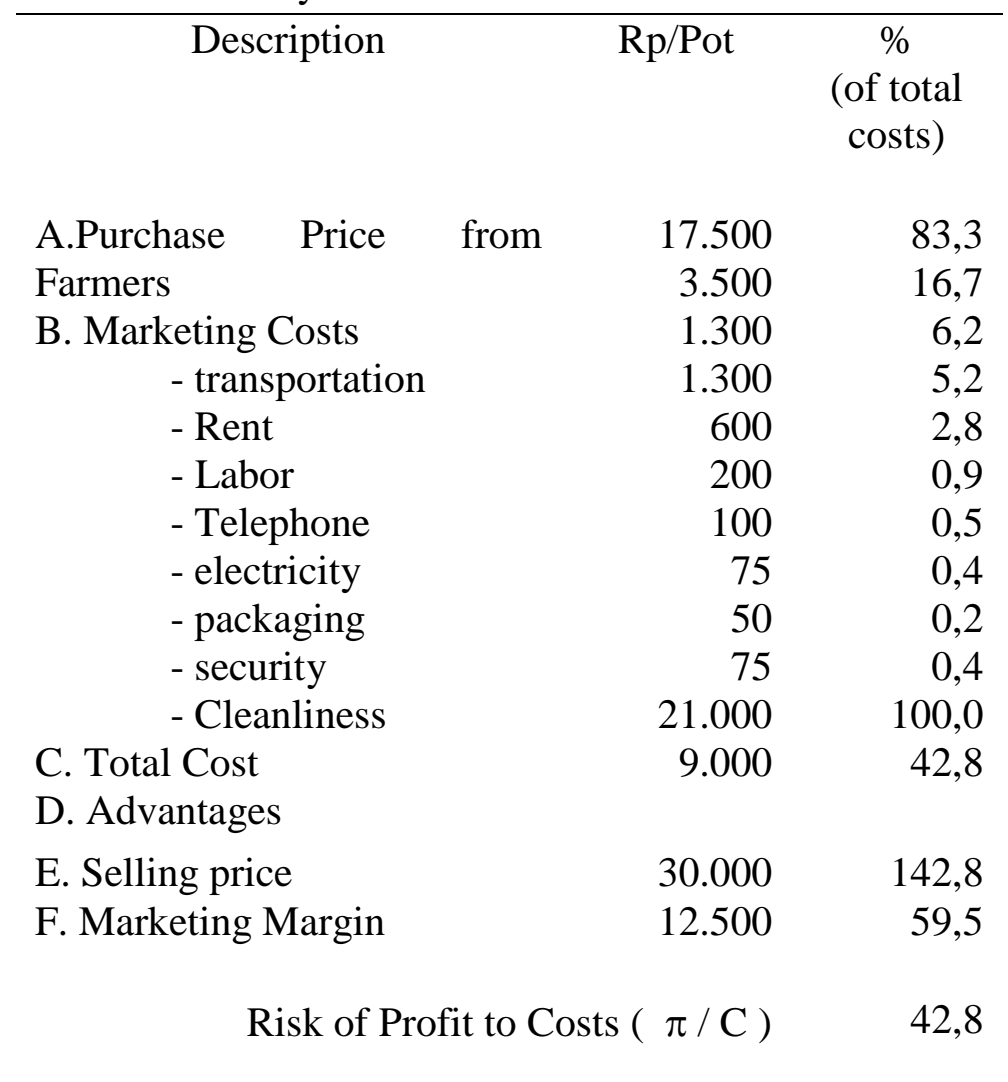

Source: Primary data processed (2016)

Components of marketing costs incurred by farmers in Ragunan Orchid Gardens as shown in Table 7 and Table 8 consist of transportation, local, labor, telephone, electricity, packaging, security, cleanliness. The cost of transportation is the costs incurred during the purchase process or once transported from the nursery to the Ragunan Orchid Garden. Costs incurred by farmers to transport dendrobium orchids ranged from $\mathrm{Rp}$. 400.00 to 750.00 per pot. Transportation costs incurred by farmers averaged Rp. 500.00 per pot.

In Table 8 it can be seen that the profit gained from each pot of dendrobium orchid plants is Rp.5,500.00 with a profit to marketing cost ratio of 45.8 percent per pot. In contrast to Table 11 . the profit gained from each pot of the dendrobium orchid plant is Rp. $8,000.00$ with a profit to marketing cost ratio of 66.6 percent per pot. This implies that for every one unit of costs incurred, the benefits obtained will be greater than one of these costs. When viewed from the profit ratio, for one rupiah spent by farmers can get their respective benefits in Table 10. amounting to Rp. 0.45 and in Table 11. amounting to Rp. 0.66.

\subsubsection{Dendrobium Orchid Marketing Margin AnalysisfromLarge Traders Outside Jakarta toRetailers OutsideJakarta}

Based on the description that has been mentioned, that large traders who buy dendrobium orchids in Ragunan Orchid Garden are large traders who come from outside Jakarta, in this study focused on large traders who come from Bekasi. Furthermore, from large traders that will be marketed to retailers, then marketed to consumers in Bekasi. Table 12 shows the analysis of the marketing margin of dendrobium orchids from large traders in Bekasi to retailers in Bekasi.

Components of marketing costs incurred as big traders in Bekasi as shown in Table 12 consist 
of transportation, local, labor, telephone, electricity, packaging, security, hygiene. The cost of transportation is the costs incurred during the process of buying from the Ragunan Orchid Garden in the biggest merchant marketing market in Bekasi. Costs incurred by large traders to transport dendrobium orchids per pot range from Rp 1,100.00 to $\mathrm{Rp} 1,500.00$. Transportation costs incurred by large traders an average of $\mathrm{Rp}$ 1,300.00 per pot.

Large traders in Bekasi use a kiosk or temporary storage area to sell dendrobium orchids directly to retailers or consumers in Bekasi and also as a place to store dendrobium orchids. The cost of renting a place ranges from Rp 1,000.00 to Rp 1,200.00 per pot for a size of \pm 025 M2. Rental costs incurred by large traders an average of $\mathrm{Rp}$ $1,100.00$ per pot.

\subsubsection{Dendrobium Orchid Marketing Margin Analysis from Retailers Outside Jakarta to Consumers Outside Jakarta.}

Retailers originating from outside Jakarta in this study are focused on tradersretailers originating from Bekasi. Retailers in Bekasi buy dendrobium orchids from big traders in Bekasi and market them to consumers in Bekasi. The retailers referred to in this study consist of retailers who market dendrobium orchids in settled locations such as roadside stalls measuring $\pm 25 \mathrm{M}^{2}$, retailers who market dendrobium orchids in cars and stay somewhere for \pm 8 hours per day, and retailers who go around marketing the dendrobium orchid using motorbikes or carts.

Analysis of marketing margins of dendrobium orchids from retailers in Bekasi to consumers in Bekasi can be seen in Table 13. Components of marketing costs incurred by retailers in Bekasi to consumers in Bekasi as shown in Table 9 consist of transportation costs, rental space, labor, telephone, electricity, packaging, cleanliness.

Table 9. Dendrobium Orchid Marketing Margin Analysis Marginfrom Retailers in Bekasi to Consumers in

\begin{tabular}{ccc}
\multicolumn{3}{c}{ Bekasi } \\
\hline Description & Rp/Pot & $\%$ \\
& & (of total costs)
\end{tabular}

\begin{tabular}{|c|c|c|}
\hline A.Buying & 30.000 & 92,3 \\
\hline Wholesalers & 2.500 & 7,7 \\
\hline B. Marketing Costs & 1.000 & 3,1 \\
\hline - transportation & 700 & 2,1 \\
\hline - Rent & 500 & 1,5 \\
\hline - Labor & 125 & 0,4 \\
\hline - Telephone & 50 & 0,2 \\
\hline - electricity & 25 & 0,1 \\
\hline - packaging & 50 & 0,2 \\
\hline - security & 50 & 0,2 \\
\hline - Cleanliness & 32.500 & 100,0 \\
\hline C. Total Cost & 12.500 & 38,5 \\
\hline D. Advantages & & \\
\hline E. Selling price & 45.000 & 138,5 \\
\hline F. Marketing Margin & 15.000 & 46,1 \\
\hline Risk of Profit to Costs $(\pi / \mathrm{C})$ & & 38,5 \\
\hline
\end{tabular}

Source: Primary data processed (2016) 
Table 10. Dendrobium Orchid MarketingAnalysis from Retailers inJakarta to Consumers in Jakarta

Description
$\%$ (of total costs)

$\begin{array}{lrrr}\text { A. Purchase Price } & \text { from } & 17.500 & 85,8 \\ \text { Farmers } & & 2.900 & 14,2 \\ \text { at TAR } & 900 & 4,4 \\ \text { B. Marketing Costs } & 1.100 & 5,4 \\ \text { - transportation } & 600 & 3,0 \\ \text { - Rent } & 125 & 0,6 \\ \text { - Labor } & 50 & 0,2 \\ \text { - Telephone } & 25 & 0,1 \\ \text { - electricity } & 50 & 0,2 \\ \text { - packaging } & 50 & 0,2 \\ \text { - security } & 20.400 & 100,0 \\ \text { - Cleanliness } & 14.600 & 71,6 \\ \text { C. Total Cost } & & \\ \text { D. Advantages } & & \end{array}$

E. Selling price

35.000

171,6

F. Marketing Margin

17.500

85,8

Risk of Profit to Costs $(\pi / \mathrm{C})$

71,6

Source: Primary data processed (2016)

\subsubsection{Dendrobium Orchid Marketing Margin Analysis from Retailers in Jakarta to Consumers in Jakarta.}

Components of marketing costs for dendrobium orchids from retailers around Jakarta who buy their merchandise from farmers in Ragunan Orchid Garden and market it around Jakarta consist of: transportation costs, rental space, labor, telephone, electricity, packaging, security, cleanliness. The complete components of marketing margins and their values are listed in Table 14.

Components of marketing costs incurred by retailers in Jakarta as shown in Table 14. consist of transportation, local, labor, telephone, electricity, packaging, security, hygiene. Transportation costs are costs incurred during the purchase process from Ragunan Orchid Garden to the retailer's marketing place in Jakarta. Costs incurred by retailers in Jakarta to transport dendrobium orchids range from Rp. 600.00 to $\mathrm{Rp}$. $1,100.00$ per pot. Transportation costs incurred by retailers an average of Rp 900.00 per pot.

Retailers in Jakarta use temporary storage or kiosks to accommodate dendrobium orchids. Rental fees range from Rp. 700.00 to Rp. 1,300.00 per pot for $\pm 25 \mathrm{M} 2$ in size. The rental fees incurred by retailers are $\mathrm{Rp} 1,100.00$ per pot. 
Retailers who use motorbikes and carts do not pay for rental premises, because in general these retailers after buying dendrobium orchids from Ragunan Orchid Garden go directly to sell dendrobium orchids.

Labor costs are wages given to assistants who work as salespeople and staff in the maintenance process for the dendrobium orchid has not been sold within 2 days to 1 week. Labor costs incurred by retailers per pot range from $\mathrm{Rp} 500.00$ to 650.00. The labor costs incurred by retailers are around Rp. 600.00 per pot. Retailers who use motorcycles and wagons do not incur costs for labor, because the retailers use their own power to sell dendrobium.

Retailers in Jakarta always try to communicate using telephone facilities with farmers in Ragunan Orchid Garden to find out and obtain market information. Telephone costs incurred by retailers per pot range from IDR 50.00 to IDR 175.00 so that the average telephone fee is IDR 125.00 per pot.

As long as the dendrobium orchid is in the retailer's storage area, watering and lighting is needed using electricity. The average electricity costs incurred by retailers per pot ranges from $\mathrm{Rp}$. 25.00 to $\mathrm{Rp} .75 .00$ so that the average electricity costs incurred by retailers is Rp. 50.00 per pot.

Packaging is needed in the process of transporting dendrobium orchids from Ragunan Orchid Garden to retailers, this is to keep dendrobium orchids fresh and undamaged. But not all retailers do the packaging, depending on the distance. Usually the further the distance from Ragunan Orchid Garden to the retailer's place, the packaging will be done. The packaging cost per pot ranges from Rp. 10.00 to Rp. 35.00 per pot. The average retailer's packaging costs are Rp. 25.00 per pot.
Security costs are costs incurred to maintain the security of dendrobium orchids while in the retailer's storage area. Security costs at the retail level are also relatively small, because the value has been calculated into the cost of renting space. The security costs incurred by retailers per pot range from IDR 25.00 to IDR 75.00. The security costs incurred by retailers averaged IDR 50.00 per pot.

Cleaning costs are costs incurred to maintain cleanliness in the retailer's storage area in Jakarta. As with security costs, the cost of cleaning is also relatively small in value because it has been calculated into the cost of renting a place. The cleaning costs incurred by retailers in Jakarta per pot ranges from Rp. 25.00 to Rp. 75.00 so that the average cleaning costs incurred by retailers are Rp. 50.00 per pot.

In Table 14. it can be seen that the profit gained from each potted dendrobium orchid plant is Rp. 14,600.00 with a profit to marketing cost ratio of 71.6 percent per pot. When viewed from the profit ratio, for one rupiah spent by large traders can get a profit of Rp. 0.71 .

\subsection{Analysis of Distribution of Marketing Margins}

Margin distribution analysis is carried out to see the extent of the spread of costs and profits at each marketing institution through the calculation of marketing margins. In addition, this analysis is carried out to determine the farmer's share or percentage of selling prices at the farm level against the prices received by consumers. In this analysis of the distribution of margins, the main marketing channels that will involve farmers, wholesalers, retailers and consumers outside Jakarta will be analyzed in this study focused on Bekasi as shown in table 15.

Table 11.Analysis of Dendrobium's Marketing Distribution with the Reference MarketIn Bekasi
Description
$\mathrm{Rp} / \mathrm{Pot}$
$\%$ (of the price consumers receive)

A. Farmers at TAR

- Cost of goods sold

10.000

22,22

- Marketing Margin

7.500

16,67 
- Marketing costs

- profit

- Selling price

B. Wholesalers

- Purchase Price from Farmers at TAR

- Marketing Margin

- Marketing costs

- profit

- Selling price

C. Retailers

-Buy Prices from Wholesalers

- Marketing Margin

- Marketing costs

- profit

- Selling price

D. Consumers

- Prices received
2.000

5.500

$17.500 \quad 38,89^{*}$

17.500

12.500

3.500

9.000

30.000

30.000

15.000

2.500

12.000

45.000

45.000
4,44

12,22

38,89

27,78

7,78

20,00

66,67

66,67

33,33

5,56

27,78

100,00

100,00

Description: * Farmer's Share Value

Table 12.Analysis of the Dendrobium OrchidMarketing Margin Distribution withthe Reference Market in Jakarta

\begin{tabular}{lcc}
\hline \multicolumn{1}{c}{ Description } & Rp/Pot & $\begin{array}{c}\% \\
\text { (of the } \\
\text { price } \\
\text { consumers } \\
\text { receive) }\end{array}$ \\
A. Farmers at TAR & & \\
- Cost of goods sold & 10.000 & 28,57 \\
- Marketing Margin & 7.500 & 21,43 \\
- Marketing costs & 2.000 & 5,71 \\
- profit & 5.500 & 15,71 \\
- Selling price & 17.500 & $50,00 *$ \\
B. Retailers & & \\
- Purchase Price from & 17.500 & 50,00 \\
$\quad$ Farmers at TAR & 17.500 & 50,00 \\
- Marketing Margin & 2.900 & 8,28 \\
- Marketing Costs & 14.000 & 41,71 \\
- profit & 35.000 & 100,00 \\
- Selling price & & \\
C. Consumers & 35.000 & 100,00 \\
- Prices received & & \\
\hline
\end{tabular}

Description: * Farmer's Share Value

In Table 11 it appears that the marketing margins of each marketing institution for dendrobium orchids are practiced evenly. The difference in marketing margins in each marketing institution that occurs due to differences in the costs to be incurred and the benefits taken by each institution are the result of differences in the marketing functions that it does. The highest marketing margin at the retailer institution is $\mathrm{Rp}$ $15,000.00$ or 33.33 percent, while the lowest marketing margin occurs to farmers in Ragunan Orchid Gardenwhich is $\mathrm{Rp} 7,500.00$ or 16.67 percent. 
The highest profit is obtained by retailers, which is $\mathrm{Rp} 12,500.00$ or 27.78 percent. Even though large traders earn less profit than retailers, which is Rp. 9,000.00 or 20.00 percent, but because the volume of sales of large traders is far more than the sales volume of retailers, big traders also get a lot of profits. The value of the farmer share in the reference market outside Jakarta is 38.89 percent.

In the analysis of the distribution of marketing margins of dendrobium orchids with the reference market in Jakarta as presented in Table 12. The following shows that retailers receive the highest marketing margin of $\mathrm{Rp}$. $17,500.00$ or 50.00 percent, the marketing margin obtained by farmers in Ragunan Orchid Garden is Rp 7,500.00 or 21.43 percent and the value of farner's share in the reference market in Jakarta is 50.00 percent.

The highest profit gained by retailers is $\mathrm{Rp}$. $14,600.00$ or 41.71 percent. Likewise with marketing costs, retailers have a sizable marketing cost of Rp 2,900.00 or 8.28 percent. While marketing costs incurred by farmers in Orchid Ragunan Park are Rp. 2,000.00 or 5.71 percent as shown in Table 16.

The results of the distribution analysis of marketing dendrobium margins with reference markets outside Jakarta and in Jakarta as shown in Tables 15 and 16, show that traders have the highest marketing margin and compared with other market institutions involved in marketing dendrobium orchids. This is caused by high selling prices as a result of relatively more expensive marketing because of the relatively small purchase volume in each purchase compared to the volume of purchases made by traders with a large amount of magnitude.

\subsection{Market Efficiency Analysis}

Ragunan Orchid Gardenhas 4 (four) forms of marketing channels, after the marketing margin analysis has been done, then it can be known that marketing efficiency is efficient for each of these marketing channels. Next is the calculation of marketing efficiency for marketing channels formed in the Ragunan Orchid Garden.

\section{FarmersConstamers}

Marketing Efficiency = Marketing Margin /

Selling pricex $100 \%$

Marketing Efficiency at Farmer Level $=$ $10,000 / 20,000 \times 100 \%=50 \%$

2. Farmers ReailersConsumers

Marketing Efficiency $=\quad$ Marketing Margin/Selling pricex 100\%

Marketing Efficiency at Farmer Level $=$ $7,500 / 17,500 \times 100 \%=42 \%$

Marketing Efficiency at the Retail Rate = $17,500 / 35,000 \times 100 \%=50 \%$

3. Farmers Larg Traders Consumer $\longrightarrow$

Marketing Efficiency $=\quad$ Marketing Margin / Selling pricex $100 \%$

Marketing Efficiency at Farmer Level $=\quad 7,500$ $/ 17,500 \mathrm{x} 100 \%=42.8 \%$

Marketing Efficiency at Large Trader Level $=$ $12,500 / 30,000 \times 100 \%=41.7 \%$

\section{Farmers —arge Traders Retaiłers}

Marketing Efficiency = Marketing Margin /

Selling pricex $100 \%$

Marketing Efficiency at Farmers Level $=$ $7,500 / 17,500 x 100 \%=42.8 \%$

Marketing Efficiency at Large Traders Level $=$ $12,500 / 30,000 \times 100 \%=41.7 \%$

Marketing Efficiency at Retailer Level $=15,000$ / $45,000 \mathrm{x} 100 \%=33.3 \%$ 
Of the 4 (four) forms of marketing channels, the value of marketing efficiency at the level of wholesalers and retailers varies considerably, between $33.3 \%$ to $50 \%$. While at the farmer level the value is almost the same for all forms of marketing channels, namely $42.8 \%$ and $50 \%$. The results of the highest marketing efficiency calculations, while the lowest marketing efficiencies are in the 4th marketing channel. This is because the 1st marketing does not involve marketing institutions in the process of delivering dendrobium orchids to consumers, while the 4th marketing channel involves marketing institutions namely wholesalers and retailers.

\section{Conclusions And Suggestions}

\subsection{Conclusion}

Based on the results of a study of the marketing margin analysis of dendrobium orchids in Ragunan Orchid Garden, South Jakarta, it can be concluded:

1. The marketing channel for dendrobium orchids formed in Ragunan Orchid Garden, South Jakarta consists of 4 (four) forms, namely:
a. FarmersComers
b. FarmersRetersConsumets
c. FarmersLarge TradersConsumers

d. Farmers Larg Traders Retailers Gotsumers

2. The marketing margin of dendrobium orchids obtained by retailers with a reference market in Bekasi has the highest value of Rp. 15,000.00 per pot. While the marketing margin of the dendrobium orchid obtained by retailers with the reference market in Jakarta also has the highest value of Rp. 17,500.00 per pot.

3. The marketing channel from farmers directly to consumers has the highest marketing efficiency that is equal to $50 \%$.

\subsection{Suggestion}

Dendrobium orchid farmers in Ragunan Orchid Gardenshould try to reduce the value of marketing margins and increase marketing efficiency. By reducing the marketing institutions involved in the marketing of dendrobium orchids, including taking part in exhibitions of ornamental plants and opening several marketing branches in areas that are still reachable by farmers.

\section{REFERENCES}

[1] Assauri, Sofjan. 2002. Manajemen Pemasaran Dasar, Konsep dan Strategi. Raja Grafindo Persada. Jakarta

[2] Andayani, Wahyu. 2007. Analisis Efisiensi Pemasaran Kacang Mete (CashewNuts) di Kabupaten Wonogiri. Skripsi. Jurusan Manajemen Hutan Fakultas Kehutanan. Universitas Gajah Mada. Yogyakarta

[3] Anonim. 2005. Anggrek Dendrobium. Info Kit. PT. Trubus Swadaya. Jakarta

[4] Darmono, Dyah Widiastoety. 2006. Agar Anggrek Rajin Berbunga. Penebar Swadaya. Jakarta

[5] Departemen Pertanian. 2004. Budidaya Tanaman Anggrek. Inspektorat Jenderal. Jakarta

[6] Departemen Pertanian. 2005. Sistem Distribusi Bahan Pangan. Badan Ketahanan Pangan. Jakarta.

[7] Gunawan, Livy Winata. 2005. Budidaya Anggrek. Penebar Swadaya. Jakarta

[8] Lestari, Sugeng Sri. 2003. Mengenal dan Bertanam Anggrek. Aneka Ilmu. Semarang.

[9] Pranowo, Agung.2006. Analisis Margin Pemasaran Rumput Laut (Eucheuma cottonii). (Studi Kasus pada Sentra Produksi Rumput Laut di Pulau Pari Kepulauan Seribu, DKI Jakarta ). Skripsi. Program Studi Agronomi. Program Kekhususan. Universitas Nasional. Jakarta.

[10] Rintoni. 2007. Taknologi Informasi Sarana Tepat Pemasaran Produk. Pusat Informasi Bisnis Kadin. Bandung.

[11] Setiawan, Herman. 2005. Usaha Pembesaran Anggrek. Penebar Swadaya. Jakarta.

[12] Sugiyono.2007. Metode Penelitian. Alfabeta. Bandung.

[13] Suryabrata, Sumadi. 2004. Metode Penelitian. Raja Grafindo Persada. Jakarta. 
[14] Tjiptono, Fandy. 1997. Strategi Pemasaran. Andi Press. Yogyakarta.

[15] Tukan, Joel M. 2000. Pemasaran Kayu dari Lahan Petani di Propinsi Lampung. World Agroforestry Center. Bogor.

[16] Umar, Husein. 2005. Metode Penelitian Untuk Skripsi dan Tesis Bisnis. Raja Grafindo Persada. Jakarta. 